\title{
Amino acids application enhances flowers insecticidal protein content in Bt cotton
}

\author{
TAMBEL Leila. I. M. ${ }^{1,2}$, ZHOU Mingyuan ${ }^{1}$, CHEN Yuan ${ }^{1}$, ZHANG Xiang ${ }^{1}$, CHEN Yuan $^{1}$ and CHEN Dehua ${ }^{*}$
}

\begin{abstract}
Background: Low insecticidal protein expression at reproductive organs affect insect resistance in Bt transgenic cotton. In order to enhance flower insecticidal protein expression, the conventional cultivar Sikang1 (S1) and the hybrid cultivar Sikang3 (S3) were used as experimental materials; the applications of selected 5 types of amino acids and 21 types of amino acids were sprayed on the flowers in 2016 and 2017 cotton growing seasons.

Results: The flower Bt protein contents increased significantly under the two amino acid treatments in both cultivars, the Bt protein concentration increased by 15.2 to $25.8 \%$ compared with the control. However, no significant differences were detected between the two treatments of amino acid application. Increased amino acid and soluble protein contents, enhanced GPT, GOT, protease,and peptidase activities were observed under the amino acid application at the flowering stage.

Conclusions: These results suggest that exterior application of the amino acids treatments could bolster the flower insecticidal protein expression.
\end{abstract}

Keywords: Bt cotton, Flower, Bt insecticidal protein, Amino acid, Nitrogen metabolism

\section{Introduction}

Bt transgenic cotton have been planted widely in China and other cotton production areas in the world (Clive 2012; Huang et al. 2010). The production of Bacillus thuringiensis (Bt) transgenic cotton decreased environmental pollution, increased worker safety by reduced chemical use, and enhanced grower income (Gould 1988; Gasser and Fraley 1989; Huang et al. 2010). The Bt cotton can encode the CryIAc protein to control the harm of Helicoverpa amigera larvae. However, the insecticidal activity is unstable, variation of insect efficiency due to altered CrylAc expression has been related to the extreme environmental factors, the silence or switch off of introduced gene, and/or developmental stage (Xia and Guo 2004; Wang et al. 2009; Chen et al. 2012a, b). However, the insect resistance expression was different in various organs and at different growth stages during a cotton growth season (Greenplate et al. 2000; Glenn 2011). The square, flower and boll usually had lower Bt toxin content than the leaf (Adamczyk and Meredith

\footnotetext{
* Correspondence: cdh@yzu.edu.cn

${ }^{1}$ Jiangsu Key Laboratory of Crop Genetics and Physiology, Co-Innovation

Center for Modern Production Technology of Grain Crops, Yangzhou

University, Yangzhou 225100, China

Full list of author information is available at the end of the article
}

2004; Shen et al. 2010), and the lowest Bt insect resistance was observed during flowering and boll formation stage in cotton growth season (Chen et al. 2005a, b; Chen et al. 2012a, b). Our previous studies found that cultivars and leaf-square regulation affected boll size, which contributed to changed Bt toxin protein content (Wang et al. 2009). Our previous studies also observed that the Bt insecticidal efficacies of square and boll were associated with nitrogen metabolism, and the Bt toxin content was impacted by protein synthesis and degradation process (Zhang et al. 2007; Chen et al. 2017). These results suggested that nitrogen and amino acid can influence Bt toxin content in Bt cotton, and exterior application of nitrogen fertilizer proved that nitrogen could increase insecticidal efficacy of Bt cotton. But little is known about the effect of amino acids application on the Bt content in Bt cotton, especially for the Bt protein content of reproductive organ. The flower is one of the first chosen reproductive organ harmed by boll worm, in order to uncover the mechanism of the impact of amino acids on insect resistance of flowers, it is necessary to study the effect of amino acids application on Bt toxin content of the flowers and the related mechanism. The current study tested the effect of amino acids application on the leaf insecticidal protein concentration during flowering period. 


\section{Materials and methods}

\section{Materials and experimental design}

Field experiments were carried out at Yangzhou University Farm, Jiangsu Province, China ( $32^{\circ} 30^{\prime} \mathrm{N}, 119^{\circ} 25^{\prime} \mathrm{E}$ ) in 2016-2017. S1 and S3, which are two widely grown Bt cotton cultivars in China, were used in this study with the planting density of 27000 (S3) and 37500 (S1) plants per hectare. Seeds were sown on April 3rd (2016) and April 7th (2017) in a plastic cover lilliputian greenhouse. Seedlings were transplanted to the field on May 15th (2016) and May 19th (2017). The soil [sandy loam texture (Typical fluvaquents, Entisols (U.S. taxonomy)) contained 22.5 and $22.1 \mathrm{~g} \cdot \mathrm{kg}^{-1}$ organic matter and 110.5 and 113.7, 21.6 and 20.9, 85.6 and $86.8 \mathrm{mg} \cdot \mathrm{kg}^{-1}$ available N-P-K in 2016 and 2017, respectively. Cultivation practices, including application of fertilizers and insecticides, chemical plant growth retardant DPC (1,1-dimethyl piperidinium chloride, $\mathrm{C}_{7} \mathrm{H}_{16} \mathrm{CIN}$ ) spray, and irrigation, were carried out following local recommendations.

Before planting, $\mathrm{K}\left(120 \mathrm{~kg} \cdot \mathrm{hm}^{-2}\right.$ as $\left.\mathrm{KCl}\right)$ and $\mathrm{P}$ (300 $\mathrm{kg} \cdot \mathrm{hm}^{-2}$ as single superphosphate) were applied. At early flowering, $\mathrm{K}\left(120 \mathrm{~kg} \cdot \mathrm{hm}^{-2}\right.$ as $\left.\mathrm{KCl}\right)$ and $\mathrm{P}\left(300 \mathrm{~kg} \cdot \mathrm{hm}^{-2}\right.$ as single superphosphate) were top-dressed. N (urea) was applied before transplanting (25\%), at early flowering (18\%), and at peak flowering (57\%). Three hundred $\mathrm{kg} \cdot \mathrm{hm}^{-2}$ is the nitrogen fertilization dose in the experiments.

The experiment was arranged with split plot designs. The main plot treatment was cultivars (S1 and S3), and the subplot treatment consisted of three amino acids treatments, which consisted of 0 (CK), 5 (A1), and 21 (A2) types of amino acids, respectively; the applied amino acid concentration was $20 \mathrm{mg} \cdot \mathrm{kg}^{-1}$. The selected five kinds of amino acids were aspartic acid, glutamic acid, proline, methionine, arginin, which affected Bt protein content remarkably based on the previous studied results (Abidallha et al. 2017). The selected 21 kinds of amino acids were aspartic acid, glutamic acid, proline, methionine, arginin, glycine, tyrosine, phenylalanine, histidine, serine, threonine, alanine, cysteine, valine, isoleucine, leucine, lysine, tryptophan, asparagine, ornithine, and glutamine. The solutions of the treatment were sprayed on the flower at 8 days before opening. And the flowers were sampled for analysis on the same day as they opened. Three replications were used in the field. Each plot consisted of $6 \mathrm{~m}$ length with rows spaced 0.9 $\mathrm{m}$ apart.

\section{Preparation of plant material Sampling}

Five flowers were harvested from the first position of the fourth to sixth fruiting branches. The flowers were mixed thoroughly before subsampling. Three subsamples of flower $(0.2 \mathrm{~g} \mathrm{FW})$ per each plot were used to determine the following parameters.

\section{The cry IAc protein content}

Immunological analysis ELISA was used to test the CrylAc content in the flower extracts as described by Chen et al. (1997).

\section{Free amino acid and soluble protein content}

Based on Yemm et al. (1955), the total free amino acid content was measured by ninhydrin assay. The Coomassie Blue dye-binding Assay of Bradford was used for total soluble protein content determination (Bradford 1976).

\section{Glutamic-pyruvic transaminase (GPT) and glutamate oxaloacetate transaminase (GOT)}

Activity flowers $(0.2 \mathrm{~g} \mathrm{FW})$ were homogenized in 0.05 mmol. $\mathrm{L}^{-1}$ Tris- $\mathrm{HCl}$, pH 7.2 buffer. The supernatant was collected after centrifugation at $26100 \mathrm{~g}$ for $10 \mathrm{~min}$ at $4{ }^{\circ} \mathrm{C}$. For GOT activity assay, $0.2 \mathrm{~mL}$ of the supernatant was added to a mixture containing $0.5 \mathrm{~mL}$ of $0.8 \mathrm{~mol} \cdot \mathrm{L}^{-1}$ alanine in $0.1 \mathrm{~mol} \cdot \mathrm{L}^{-1}$ Tris- $\mathrm{HCl}$ (pH 7.5), $0.1 \mathrm{~mL}$ of 2 $\mathrm{mmol} \cdot \mathrm{L}^{-1}$ pyriodoxal phosphate solution, and $0.2 \mathrm{~mL}$ of $0.1 \mathrm{~mol} \cdot \mathrm{L}^{-1}$ 2-oxoglutarate solution. The reaction mixture was incubated at $37^{\circ} \mathrm{C}$ for $10 \mathrm{~min}$ followed by adding $0.1 \mathrm{~mL}$ of a $0.2 \mathrm{~mol} \cdot \mathrm{L}^{-1}$ trichloroacetic acid solution to stop the reaction. The color intensity was read at $520 \mathrm{~nm}$. The GPT activity assay was similar to the GOT assay. In GPT assay, $0.5 \mathrm{~mL}$ of a $0.1 \mathrm{~mol} \cdot \mathrm{L}^{-1}$ buffered aspartate solution in the reaction mixture was used instead of $0.5 \mathrm{~mL}$ of a $0.8 \mathrm{~mol} \cdot \mathrm{L}^{-1}$ alanine in $0.1 \mathrm{~mol} \cdot \mathrm{L}^{-1}$ Tris- $\mathrm{HCl}$ ( $\mathrm{pH} 7.5$ ) (Tonhazy et al. 1950).

\section{Protease and peptidase activity}

Flowers $(0.8 \mathrm{~g})$ were homogenized at $4{ }^{\circ} \mathrm{C}$ in $1 \mathrm{~mL}$ of $\beta$ mercaptoethanol extraction buffer (a mixture of ethylene glycol, sucrose, and phenyl methyl sulfonyl fluoride, $\mathrm{pH}$ 6.8). The supernatant was collected to estimate the square protease. Protease activity was determined spectrophotometrically at $400 \mathrm{~nm}$ using azocasein as a substrate (Vance and Johnson 1979) and expressed as mg protein. $\mathrm{g}^{-1}$ flower fresh weight $(\mathrm{FW}) \cdot \mathrm{h}^{-1}$. Flowers samples $(0.5 \mathrm{~g})$ were homogenized at $4^{\circ} \mathrm{C}$ in $8 \mathrm{~mL}$ of Tris$\mathrm{HCl}$ extraction buffer (a mixture of $4 \mathrm{mmol} \cdot \mathrm{L}^{-1}$ DTT, 4 mmol. $\mathrm{L}^{-1}$ EDTA, 1\% PVP, pH 7.5). The supernatant (0.4 $\mathrm{mL}$ ) was collected by centrifugation at $15000 \mathrm{~g}$ for 30 min at $4{ }^{\circ} \mathrm{C}$ and added to a mixture $[0.4 \mathrm{~mL}$ acetate buffer ( $\mathrm{pH} 4.8), 1 \%$ bovine hemoglobin compounded with $0.2 \mathrm{~mL}$ acetate buffer $(\mathrm{pH} 4.8)]$ and incubated at $38^{\circ} \mathrm{C}$ for $60 \mathrm{~min}$. One $\mathrm{mL}$ of a $10 \%$ trichloroacetic acid solution was added to stop the reaction. The supernatant collected by centrifugation $(4000 \mathrm{~g}$ for $5 \mathrm{~min}$ ) was used for amino acid content analysis by ninhydrin assay (Yemm et al. 1955), and peptidase activity was expressed as $\mu \mathrm{mol}$ amino acid.g ${ }^{-1}$ flower fresh weight. $\mathrm{h}^{-1}$. 


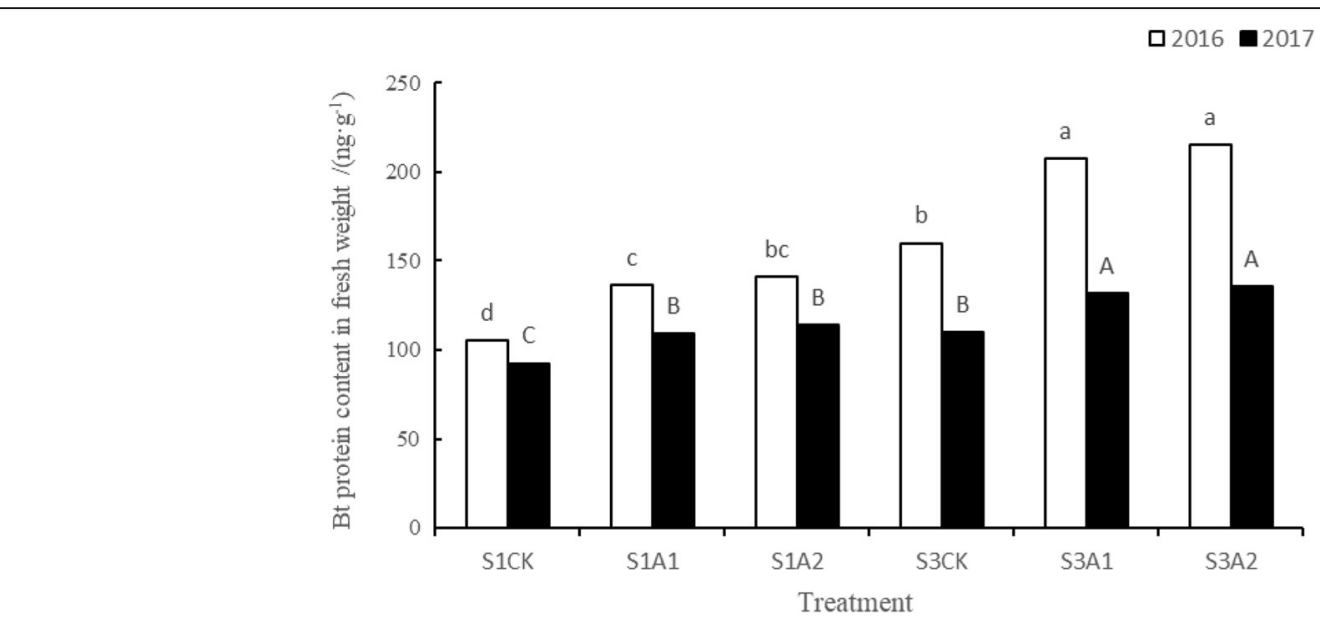

Fig. 1 The effect of application of 5 amino acids and 21 amino acids on flower Bt protein contents at flowering period in Bt cotton Sikang1(S1) and Sikang3 (S3). A1, A2, CK represented 5 amino acids treatment, 21 amino acids treatment, and the control, respectively. Differences between treatments within the same year labeled by the same letter are statistically not significant (LSD test at 0.05 significance level)

\section{Results}

\section{Flower insecticidal protein concentration under the} amino acids application treatments

Similar trends were observed for flower Bt protein content under different amino acids application treatments in both years. In comparison with the control, the flower $\mathrm{Bt}$ protein contents increased significantly under the two amino acid treatments in both cultivars (Fig. 1). However, no significant differences were detected between the two treatments of amino acid application. In 2016, the increase caused by treatments $\mathrm{A} 1$ and $\mathrm{A} 2$ on flowers insecticidal protein contents were 22.7 and $25.3 \%$ in S1 and 22.9 and $25.8 \%$ in S3. In 2017, amino acids application treatments A1 and A2 increased the flower Bt protein contents by 15.2 and $18.8 \%$ in $\mathrm{S} 1$ and by 16.4 and $19.1 \%$ in S3. Cultivar S3 had higher flower Bt protein content than that of cultivar S1.

\section{Flower nitrogen metabolism under the amino acids application treatments}

GPT and GOT, the key enzymes in amino acid synthesis, their activities increased remarkably under the amino acid application treatments in both years (Table 1). Compared with the control, the increase caused by amino acids application treatments A1 and A2 on flower GOT activity was 31.1 and $34.6 \%$ in Sikang1 and 40.3 and $51.4 \%$ in Sikang3 in 2016. In 2017, amino acids application treatments A1 and A2 increased the flower GOT activity by 25.0 and $39.0 \%$ in Sikang1 and by 28.0 and $34.7 \%$ in Sikang3. Similar results for GPT activity were also detected in both cultivars in 2016 and 2017.

Flower protease activities were increased significantly with increasing amino acids application composition in both years (Table 2). Greater increase was observed at A2 treatment than A1 for both enzyme activities in both years. In 2016, the increase caused

Table 1 The effect of application of 5 amino acids and 21 amino acids on flower GOT and GPT activities of the two Bt cotton cultivars at flowering period

\begin{tabular}{|c|c|c|c|c|}
\hline \multirow[t]{2}{*}{ Treatment } & \multicolumn{2}{|c|}{ GOT activity in fresh weight $/\left(\mu \mathrm{mol} \cdot \mathrm{g}^{-1} \cdot \mathrm{h}^{-1}\right)$} & \multicolumn{2}{|c|}{ GPT activity in fresh weight $/\left(\mu \mathrm{mol} \cdot \mathrm{g}^{-1} \cdot \mathrm{h}^{-1}\right)$} \\
\hline & 2016 & 2017 & 2016 & 2017 \\
\hline S1CK & $6.54^{d}$ & $6.97^{e}$ & $3.59^{\mathrm{d}}$ & $3.75^{d}$ \\
\hline S1A1 & $8.58^{b c}$ & $8.68^{\mathrm{cd}}$ & $6.51^{c}$ & $6.66^{c}$ \\
\hline $\mathrm{S} 1 \mathrm{~A} 2$ & $8.81^{b}$ & $9.67^{\mathrm{bc}}$ & $6.63^{b c}$ & $7.33^{b c}$ \\
\hline S3CK & $7.20^{\mathrm{cd}}$ & $7.54^{d}$ & $5.23^{\mathrm{d}}$ & $4.66^{d}$ \\
\hline S3A1 & $10.10^{\mathrm{a}}$ & $9.67^{\mathrm{ab}}$ & $7.25^{\mathrm{ab}}$ & $7.48^{\mathrm{ab}}$ \\
\hline S3A2 & $10.90^{\mathrm{a}}$ & $10.16^{a}$ & $7.45^{\mathrm{a}}$ & $8.61^{a}$ \\
\hline
\end{tabular}

Note: S1 and S2 indicate the conventional Bt cultivar Sikang1 and hybrid Bt cultivar Sikang 3, respectively. A1, A2, CK represent 5 amino acids treatment, 21 amino acids treatment, and the control, respectively. Differences between treatments within the same year labeled by the same letter are statistically not significant (LSD test at 0.05 significance level) 
Table 2 The effect of application of 5 amino acids composition and 21 amino acids composition on flower protease and peptidase activities of the two Bt cotton cultivars at flowering period

\begin{tabular}{|c|c|c|c|c|}
\hline \multirow[t]{2}{*}{ Treatment } & \multicolumn{2}{|c|}{ Protease activity in fresh weight $/\left(\mathrm{mg} \cdot \mathrm{g}^{-1} \cdot \mathrm{h}^{-1}\right)$} & \multicolumn{2}{|c|}{ Peptidase activity in fresh weight $/\left(\mu \mathrm{mol} \cdot \mathrm{g}^{-1} \cdot \mathrm{h}^{-1}\right)$} \\
\hline & 2016 & 2017 & 2016 & 2017 \\
\hline S1CK & $54.6^{\mathrm{d}}$ & $47.5^{\mathrm{e}}$ & $170.2^{d}$ & $170.2^{c}$ \\
\hline S1A1 & $74.4^{\mathrm{bc}}$ & $75.1^{\mathrm{bc}}$ & $245.5^{c}$ & $251.8^{\mathrm{b}}$ \\
\hline S1A2 & $76.3^{b}$ & $61.3^{\mathrm{cd}}$ & $254.3^{\mathrm{bc}}$ & $257.3^{\mathrm{b}}$ \\
\hline S3CK & $69.2^{\mathrm{cd}}$ & $55.5^{\mathrm{de}}$ & $176.0^{d}$ & $168.0^{c}$ \\
\hline S3A1 & $95.7^{\mathrm{a}}$ & $90.0^{\mathrm{ab}}$ & $285.0^{\mathrm{ab}}$ & $333.9^{\mathrm{a}}$ \\
\hline S3A2 & $108.5^{\mathrm{a}}$ & $93.8^{\mathrm{a}}$ & $323.6^{\mathrm{a}}$ & $369.7^{\mathrm{a}}$ \\
\hline
\end{tabular}

Note: S1 and S2 indicate the conventional Bt cultivar Sikang1 and hybrid Bt cultivar Sikang 3, respectively. A1, A2, CK represent 5 amino acids treatment, 21 amino acids treatment, and the control, respectively. Differences between treatments within the same year labeled by the same letter are statistically not significant (LSD test at 0.05 significance level)

by amino acids application treatments $\mathrm{A} 1$ and $\mathrm{A} 2$ on flowers protease activity were 36.3 and $39.7 \%$ in S1 and 38.3 and $56.8 \%$ in S3. In 2017, amino acids application treatments $\mathrm{A} 1$ and A2 increased the flower protease activity by 58.1 and $29.1 \%$ in S1 and by 62.2 and $69.0 \%$ in S3. Similar characteristics were observed for flower peptidase activities.

Enhanced flowers amino acid and soluble protein content were observed for both years (Table 3). Compared with the control, greater increase for soluble protein content of flower was detected at A2 treatment, and less increase was observed at A1 treatment. The increase caused by amino acids application treatments A1 and A2 on flowers soluble protein content were 68.4 and $73.6 \%$ in S1 and 58.5 and 69.9\% in S3 in 2016. In 2017, amino acids application treatments A1 and A2 increased the flowers soluble protein content by 37.0 and $64.0 \%$ in $\mathrm{S} 1$ and by 22.0 and $31.9 \%$ in S3. Similar results for flower amino acids were also detected in both cultivars in 2016 and 2017.

Relationship between nitrogen metabolic enzyme activity, chemicals and Bt protein concentration in Bt cotton flowers There was a significant positive correlation between flower Bt insecticidal protein content with protein metabolism related enzyme activities (Table 4). In addition, flower Bt protein content exhibited a significant positive correlation with amino acid content in $2016\left(r=0.849^{*}\right)$ and $2017\left(r=0.874^{*}\right)$, and a significant positive correlation with soluble protein content in $2016(r=0.839)$ and $2017\left(r=0.997^{* * 1 *}\right)$. The correlation was highest between Bt contents with protease, followed by Bt contents with soluble protein, and lowest between $\mathrm{Bt}$ contents and GOT. Higher correlation was observed in 2017, but no differences were noted between cultivars S1 and S3.

\section{Discussion}

\section{Amino acid application enhanced flower Bt protein concentration in Bt cotton}

The extreme environmental conditions, such as high/ low temperature, high/low humidity, water deficit, soil salinity, reduced the Bt toxin content, which was related to altered nitrogen metabolism (Chen et al. $2005 \mathrm{a}, \mathrm{b}, 2013,2012 \mathrm{a}, \mathrm{b})$. In these processes, the content of free amino acid and soluble protein content changed, and they were closely correlated with the $\mathrm{Bt}$ toxin content. These studied results suggest that nitrogen and amino acid can influence Bt toxin content

Table 3 The effect of application of 5 amino acids and 21 amino acids on flower soluble protein and amino acid content of the two Bt cotton cultivars at flowering period

\begin{tabular}{|c|c|c|c|c|}
\hline \multirow[t]{2}{*}{ Treatment } & \multicolumn{2}{|c|}{ Soluble protein content in fresh weight $/\left(\mu \mathrm{mol} \cdot \mathrm{g}^{-1} \cdot \mathrm{h}^{-1}\right)$} & \multicolumn{2}{|c|}{ Amino acid content in fresh weight $/\left(\mu \mathrm{mol} \cdot \mathrm{g}^{-1} \cdot \mathrm{h}^{-1}\right)$} \\
\hline & 2016 & 2017 & 2016 & 2017 \\
\hline S1CK & $1.7^{\mathrm{e}}$ & $0.7^{d}$ & $5.8^{\text {cd }}$ & $2.8^{c}$ \\
\hline S1A1 & $2.9^{c}$ & $1.0^{\mathrm{cd}}$ & $6.5^{\mathrm{bc}}$ & $4.5^{\mathrm{b}}$ \\
\hline S1A2 & $3.0^{\mathrm{bc}}$ & $1.2^{c}$ & $6.7^{\mathrm{b}}$ & $5.1^{\mathrm{b}}$ \\
\hline S3CK & $2.2^{d}$ & $2.3^{\mathrm{b}}$ & $5.5^{d}$ & $4.9^{\mathrm{b}}$ \\
\hline S3A1 & $3.5^{\mathrm{ab}}$ & $2.8^{\mathrm{a}}$ & $8.1^{\mathrm{a}}$ & $6.9^{\mathrm{a}}$ \\
\hline S3A2 & $3.7^{\mathrm{a}}$ & $3.0^{\mathrm{a}}$ & $8.6^{\mathrm{a}}$ & $7.3^{\mathrm{a}}$ \\
\hline
\end{tabular}

Note: S1 and S2 indicate the conventional Bt cultivar Sikang1 and hybrid Bt cultivar Sikang 3, respectively. A1, A2, CK represent 5 amino acids treatment, 21 amino acids treatment, and the control, respectively. Differences between treatments within the same year labeled by the same letter are statistically not significant (LSD test at 0.05 significance level) 
Table 4 Relationship ( $R$ value) between nitrogen metabolic enzyme activity, chemicals and Bt protein concentration in Bt cotton flowers

\begin{tabular}{lllllll}
\hline Year & GPT & GOT & Protease & Peptidase & Amino acid & Soluble protein \\
\hline 2016 & $0.962^{* *}$ & 0.788 & $0.944^{* *}$ & 0.786 & $0.849^{*}$ & $0.839^{*}$ \\
2017 & $0.880^{*}$ & $0.881^{*}$ & $0.918^{* *}$ & $0.953^{* *}$ & $0.874^{*}$ & $0.997^{* *}$ \\
\hline
\end{tabular}

Note: * and ** indicate that the correlation is significant at 0.05 and 0.01 level, respectively

in Bt cotton, and the application of nitrogen fertilizer proved that nitrogen could increase insecticidal efficacy of Bt cotton leaves (Yang et al. 2005; Pettigrew and Adamczyk 2006; Dong et al. 2000; Zhang and Wen 2011; Dai et al. 2012; Manjunatha 2015). Improvement of boll shell insecticidal protein by decreasing nitrogen fertilizer rates was reported in $\mathrm{Bt}$ cotton (Chen et al. 2018). Since nitrogen fertilizer plays an important role in regulating toxin content in Bt transgenic cotton, amino acid, as the basic components of protein, might impact Bt protein content. In our present study, compared with the control, the flower Bt protein contents increased significantly under both amino acid treatments in both cultivars. However, no significant differences were detected between the two amino acid treatments. These results suggested that amino acid application could enhance flower Bt protein concentration in Bt cotton.

\section{Increased protein synthesis and protein degradation by exterior amino acid application caused elevated $\mathrm{Bt}$ toxin content in flower}

The amino acid application enhanced soluble protein content, amino acid content, protease and peptidase activities, GPT and GOT activities. It is evident that protein degradation and synthesis were increased remarkably in flower under amino acid application, as reflected by enhanced protease and peptidase activities, and GPT and GOT activities. Thus, the enhanced protein metabolism contributed to the increased protein concentration. As a part of the total soluble protein, Bt protein in flower also increased under amino acid application. In our present study, flower Bt protein content had a significant positive correlation with amino acid content and soluble protein content. Our results were consistent with previous studies. The reduced insecticidal protein concentration under extreme environmental conditions, such as high/low temperature, high/low humidity, water deficit, soil salinity, was all related to altered nitrogen metabolism (Chen et al. 2005a, b, 2013, 2012a, b). Therefore, GPT and GOT activity, and the activity of protease and peptidase in nitrogen metabolism were associated with the variation of Bt protein concentration in response to amino acid application in Bt transgenic cotton.

\section{Conclusions}

This study showed that exterior application of the amino acids, especially the 21 amino acids application, could bolster the flower insect resistance, which was a result of increased protein metabolism.

\section{Abbreviations}

ELISA: Enzyme-linked immunosorbent assay; GOT: glutamate oxaloacetate transaminase; GPT: glutamic-pyruvic transaminase

\section{Acknowledgments \\ Not applicable.}

\section{Authors' contributions}

Tambel LIM and Zhou MY performed the experiments and analyzed the data; Chen $Y$ and Chen DH conceived and designed the research; Tambel LIM and Zhou MY wrote the paper; Chen $Y$ and Zhang $X$ revised the manuscript. All authors read and approved the final manuscript.

\section{Funding}

The Projects \#2017YFD0201306, \#2018YFD0100406 supported by the National Key R\&D Program of China; \#31671613 supported by National Natural Science Foundation of China. Project funded by the Priority Academic Program Development of Jiangsu Higher Education Institutions, China (PAPD). Project \#2016PCTS-1 supported by the Chinese academy of agricultural sciences' engineering science and technology innovation fund.

Availability of data and materials

No other data related to this study is available at this time.

Ethics approval and consent to participate

Not applicable.

Consent for publication

Not applicable.

\section{Competing interests}

The authors declare that they have no competing interests.

\section{Author details \\ 'Jiangsu Key Laboratory of Crop Genetics and Physiology, Co-Innovation Center for Modern Production Technology of Grain Crops, Yangzhou University, Yangzhou 225100, China. ${ }^{2}$ Agricultural Research Cooperation, Biotechnology and Biosafety Research Center, Khartoum, Sudan.}

Received: 30 January 2019 Accepted: 22 May 2019

Published online: 26 June 2019

\section{References}

Abidallha EHMA, Li Y, Li H, et al. Amino acid composition and level affect Bt protein concentration in Bt cotton. Plant Growth Regul. 2017;82:439-46. https://doi.org/10.1007/s10725-017-0270-7.

Adamczyk JJ, Meredith WR. Genetic basis for the variability of CrylAc expression among commercial transgenic Bacillus thuringiensis (Bt) cotton cultivars in the United States. J Cotton Sci. 2004;8:17-23.

Bradford MM. A rapid and sensitive method for the quantitation of microgram quantities of protein utilizing the principle of protein-dye binding. Anal Biochem. 1976;72:248-54. https://doi.org/10.1016/0003-2697(76)90527-3. 
Chen D, Ye G, Yang C, et al. Effect of introducing Bacillus thuringiensis gene on nitrogen metabolism in cotton. Field Crop Res. 2005a;92:1-9. https://doi.org/ 10.1016/j.fcr.2003.11.005 .

Chen $D$, Ye G, Yang $C$, et al. The effect of the high temperature on the insecticidal properties of the cotton. Environ Exp Bot. 2005b;53:333-42. https://doi.org/10.1016/j.envexpbot.2004.04.004.

Chen S, Wu J, He X, et al. Quantification using elisa of Bacillus thuringiensis insecticidal protein expressed in the tissue of transgenic insect-resistant cotton. Jiangsu J Agric. 1997;13:154-6.

Chen $Y$, Wen $Y$, Chen $Y$, et al. Effects of extreme air temperature and humidity on the insecticidal expression level of Bt cotton. J Integr Agric. 2012a;11:1836-44. https://doi.org/10.1016/s2095-3119(12)60188-9.

Chen $Y$, Chen $Y$, Wen $Y$, et al. The effects of the relative humidity on the insecticidal expression level of Bt cotton during bolling period under high temperature. Field Crop Res. 2012b;131:141-7. https://doi.org/10.1016/j.fcr. 2012.08.015.

Chen Y, Li Y, Chen Y, et al. Planting density and leaf-square regulation affected square size and number contributing to altered insecticidal protein content in Bt cotton. Field Crop Res. 2017;205:14-22. https://doi.org/10.1016/j.fcr.2017. 02.004

Chen Y, Li YB, Zhou MY, et al. Nitrogen (N) application gradually enhances boll development and decreases boll shell insecticidal protein content in $\mathrm{N}$ deficient cotton. Frontiers in Plant Science, 2018, 9:51. https://doi.org/10. 3389/fpls.2018.00051.

Chen $Y$, Wen $Y$, Chen $Y$, et al. The recovery of bt toxin content after temperature stress termination in transgenic cotton. Span J Agric Res. 2013;11:438-46. https://doi.org/10.5424/sjar/2013112-2854.

Clive J. The development state for commercial Biotechnology andtransgenic crops. China Biotechnol. 2012;32(1):1-14.

Dai $J$, Dong HZ, Duan LS, et al. Effects of nitrogen fertilization on bt cotton growth and bt protein concentration in leaves under salinity stress. Cotton Science. 2012;24:303-11. https://doi.org/10.3969/j.issn.1002-7807.2012.04.003.

Dong Z, He Z, Zhai X. The nitrogen metabolized character in leaves of transgenic Bt cotton Nucotn 33B and its regulation. Cotton Sci. 2000;12:113-7.

Gasser C, Fraley R. Genetically engineering plants for crop improvement. Science. 1989;244(4910):1293-9. https://doi.org/10.1126/science.244.4910.1293.

Glenn DS. Field versus farm warangal: Bt cotton, high yields, and larger questions. World Dev. 2011;3:387-398. https://doi.org/10.1016/j.worlddev.2010.09.008.

Gould F. Evolutionary biology and genetically engineered crops: consideration of evolutionary theory can aid in crop design. Bioscience. 1988;38:26-33. https://doi.org/10.2307/1310643.

Greenplate J, Penn SR, Mullins JW, et al. Seasonal CrylAc levels in DP50B: the "Bollgard ${ }^{\oplus}$ basis" for Bollgard II. Proceedings. 2000;2:1039-41.

Huang J, Mi J, Lin H, et al. A decade of Bt cotton in Chinese fields: assessing the direct effects and indirect externalities of Bt cotton adoption in China. Sci China Life Sci. 2010;53:981-91. https://doi.org/10.1007/s11427-010-4036-y.

Manjunatha SB, Biradar DP, Aladakatti YR. Effect of nitrogen levels and potassium nitrogen ratios( $\mathrm{k}: \mathrm{N}$ ratio) on endotoxin expression in bt cotton. Biochem Cell Arch. 2015;15:469-73.

Pettigrew WT, Adamczyk JJ. Nitrogen fertility and planting date effects on lint yield and Cry1Ac (Bt) endotoxin production. Agronomy Journal. 2006;98:69197. https://doi.org/10.2134/agronj2005.0327.

Shen $\mathrm{P}$, Lin K, Zhang Y, et al. Seasonal expression of Bacillus thuringiensis insecticidal protein and the control to cotton bollworm in different varieties of transgenic cotton. Cotton Sci. 2010;22:393-7. https://doi.org/10.1080/ 00949651003724790

Tonhazy N, White N, Umbriet W. Colorimetric assay of glutamic-pyruvic transaminase. Arch Biochem Biophys. 1950;28:36-8.

Vance $C P$, Johnson LE. Nitrogen fixation, nodule development, and vegetative regrowth of alfalfa (Medicago sativa L.) following harvest. Plant. Physiol. 1979; 67:1198-203. https://doi.org/10.1104/pp.64.1.1.

Wang Y, Ye G, Luan N, et al. Boll size affects the insecticidal protein cotton in Bacillius thuringiensis (Bt) cotton. Field Crop Res. 2009;110:106-10. https://doi. org/10.1016/j.fcr.2008.07.008 .

Xia L, Guo S. The expression of Bt toxin gene under different thermal treatments. Sci Agric Sin. 2004;11:1733-7.

Yang CQ, Xu LH, Yang DY. Effects of nitrogen fertilizer on the bt-protein content in transgenic cotton and nitrogen metabolism mechanism. Cotton Science. 2005;17(4):227-31. https://doi.org/10.3969/j.issn.1002-7807.2005.04.007.

Yemm E, Cocking E, Ricketts R. The determination of amino-acids with ninhydrin. Analyst. 1955;80:209-14. https://doi.org/10.1039/AN9558000209.
Zhang X, Zhang L, Ye G, et al. The impact of introducing the Bacillus thuringiensis gene into cotton on boll nitrogen metabolism. Environ Exp Bot. 2007;61: 175-80. https://doi.org/10.1016/j.envexpbot.2007.05.008 .

Zhang G, Wen S. Effects of salt stress on bt protein content and nitrogen metabolism of transgenic bt cotton. Acta Agric Boreali-Occidentalis Sin. 2011; 20:106-9. https://doi.org/10.3969/j.issn.1004-1389.2011.06.023.
Ready to submit your research? Choose BMC and benefit from:

- fast, convenient online submission

- thorough peer review by experienced researchers in your field

- rapid publication on acceptance

- support for research data, including large and complex data types

- gold Open Access which fosters wider collaboration and increased citations

- maximum visibility for your research: over $100 \mathrm{M}$ website views per year

At BMC, research is always in progress.

Learn more biomedcentral.com/submissions 